\title{
The Dynamic Website of Islamic History in Gresik as a Historical Learning Medium
}

\author{
Abdul Rokhim ${ }^{1 *}$, Naomi Haswanto ${ }^{2}$ \\ ${ }^{1}$ Institut Teknologi Bandung, Indonesia \\ ${ }^{2}$ Institut Teknologi Bandung, Indonesia \\ *Corresponding author.Email: abdrokhim09@gmail.com
}

\begin{abstract}
Gresik which is currently known as an industrial city has been known since the 11th century when it grew into a center of inter-island trade and spread to various countries. Gresik also has a variety of history, especially Islamic history. However, many people in Gresik do not know the history of their city. This is dangerous because historical cities are part of social identity. This study aims to design historical learning media. In making this dynamic website, we will use the design thinking method through the stages of empathy, define, ideate, prototype and test, the research will collect various types of Islamic historical information in Gresik and formulate a map which will be summarized on the website. This media can be used as a promotional medium that Gresik has the oldest Islamic history in Java. In addition, it can be used as a historical collection of Gresik. In this study, several analyzes will be carried out on the effectiveness of mapping projections of Islamic history learning media in Gresik based on dynamic websites in accordance with the effective and easily accessible answers to the needs and desires of the community. The result of this research is an integrated system of Gresik historical activities based on a dynamic website that can be mapped from all regions. In addition, the research will also create an information data center containing open historical data. The data center can be accessed by anyone without time and distance restrictions.
\end{abstract}

Keywords: History, Gresik, Dynamic Website

\section{INTRODUCTION}

Gresik is a city that has the oldest Islamic history in the archipelago, this is evidenced by the archaeological discovery of the tomb of Fatimah bin Maimun which is almost 1000 years old [1]. However, despite its old history, not many people know about Gresik's history. In history the most important thing in human life is the ability to store memories. Keep memories of the stages of life continuously from the past until death takes life. The past needs to be known as a foothold in the present and the future. In order to pass on the past to the next generation there needs to be activities, in the form of reconstruction (rebuilding) of the past so that the course of past events can be fully described [2].

Being a city close to the capital city of East Java, Surabaya, Gresik is indeed an interesting case study. Gresik is known as a city for Muslim students because it has a very strong Islamic nuance. There are many cultures and relics related to Islamic history. In addition, there are also many Islamic-based education centers (pesantren). However, on the other hand, the city of Gresik is also known as an industrial city. According to data from the Central Statistics Agency in 2014, Gresik is the most densely populated industrial city in East Java. In addition, Gresik also has the highest intake of East Java. This is of course followed by high income or salary in Gresik. Gresik is not only dominated by large companies, but Gresik is also known as a producer of handicrafts and crafts for small and medium enterprises. In 2014, more than 500,000 small and medium enterprises continued to grow in Gresik. The superior products produced in the city of Gresik are: songkok, mukenah (prayer clothes), Muslim clothing, sarongs, traditional agricultural products, food, crafts, and others in this case can be the basis that Gresik has a strong Islamic history to influence business and the life of the local community. 
On the other hand, Gresik is known as the industrial city, Gresik which is a sub-regional development section (SWPB) cannot be separated from the activities of the Kertasusila Gate development sub-area (Gresik, Bangkalan, Surabaya, Sidoarjo, Lamongan). Including one part of the 9 subregions of East Java development whose activities are directed at the agricultural, industrial, trade, maritime, education and tourism industries [3].

The tourism industry in Gresik is not only natural tourism but also religious tourism and religious tourism which contributes to many tourists from outside the region who want to know the history of Gresik. In 2017, the Ministry of Tourism of Lokot Ahmad Enda also said that he wanted to make religious tourism in Gresik a reference for tourist destinations for foreign tourists. The thing that needs to be underlined in making religious tourism so that it can satisfy visitors is that there is clear information so that visitors know more about the history and stories of Islamic history in Gresik. and also a location map that shows access anywhere that is interconnected [4].

To support introducing the history of Gresik to the wider community, it is necessary to have a supporting media. In today's modern era, one of the media that is close to the community and easily accessible is a website that can be accessed from various platforms. The dynamic website is expected to make it easier for the public to access information and increase tourists about the history of Gresik. This dynamic website that will be created can later be a solution for the historical information center in Gresik.

\section{HISTORY OF ISLAM IN GRESIK}

Archaeological data show that Islam already existed in Java at the end of the XI century. The data is in the form of an inscription on a tomb (tombstone) located in Leran Village, Manyar District, Gresik Regency. The ancient Islamic tomb complex occupies an area of $2,280 \mathrm{~m}^{2}$, located on the banks of the Manyar River which is one of the water transportation routes from the coast to the interior.

In this burial complex there is one tomb with a cupola building of white stone which has Arabic inscriptions on its tombstone. The reading of the inscription states the name of a woman, Fatimah Bint Maimun Bin Hibatallah, who died on 7 Rajab $475 \mathrm{H}$ or coincided with November 25, 1082). The letters used to write on the tombstone use Kuffi (Arabic) letters. The evidence shows that around the XI century there was already an Islamic community around Gresik[2].

The existence of the tomb of Fatimah Binti Maimun Bin Hibatallah in Gresik is the oldest evidence of Islamic-style remains in Indonesia. This emphasizes the role of Gresik in the past, which has existed for a long time and has become one of the main destinations for trade from other regions. However, until now knowledge about the existence of the Leran Site is still limited, no more than what is written on the oldest tombstone. It is as if the data about this tomb stands alone, not yet searched for its relationship with history or other supporting data. Based on written and archaeological data, it appears that the Leran area is one of the areas associated with the oldest Islamization process on the north coast of Java, as well as an area of economic activity, especially in Southeast Asia.

The history of Gresik is almost inseparable from the history of the development of Islam in East Java and Indonesia. Reports from foreign traders who have stopped in Gresik are very clear about the condition of Gresik and its development from time to time. In addition, based on various inscriptions on ancient Islamic tombs in Gresik, it is known the development of the spread of Islam in Gresik. In fact, we can know the role and development of the spread of Islam from various chronicle sources studied by D. L. Monier in the first half of the nineteenth century. These studies continue to develop until now, even though they only see Gresik as an object for studies on the spread of Islam [2].

In the story above, it becomes the basis that Gresik is a major point of influence in the spread of Islam and the source of all historical events will be the most important part of the data to be used as a guide to the community about the importance of history and its influence to this day.

\section{WEBSITE AS DYNAMIC MEDIA}

Gresik has been known since the 11th century and since then the city of Gresik has developed into a trading center. Trade activities in Gresik are well known not only between islands, but also widely among countries. According to the Center for Statistics Agency Data 2012[5], Gresik is a destination frequently visited by Chinese trade, Arab trade, Gujarat trade, Siamese trade, and others. This certainly makes Gresik have quite a lot of Islamic historical heritage and quite a lot of characters who have become Gresik's icons, such as: Sunan Giri and Sheikh Maulana Malik Ibrahim. 
In order to communicate the history of Gresik, we need an appropriate and effective media. Website is one option that is considered effective because the website is a popular media, especially if it is associated with Gresik's own target. A website is a collection of pages that display a variety of information, data, text, still or moving data, animation, sound, video, or a combination of these, both static and dynamic, which form a series of interconnected buildings where each is linked to a page. network or hyperlink [6].

Usually Web page documents are written in Hyper Text Markup Language (HTML) format, which can be accessed via HTTP. HTTP is a protocol for conveying various information from a website server to be displayed to the user or users through a web browser. The website consists of several types. According to Altstiel and Grow[6]. There are 3 types of websites that are most often used, including is as follows :

1. Static Websites are websites that have pages that do not change. What this means is that making changes to the page can only be done manually by editing the code into the structure of the website itself.

2. Dynamic Websites are websites that have a structure that is intended to be updated as often as possible. Usually in addition to the main ones that can be accessed by users (users). In general, a backend is also provided, namely a page for editing website content.

3. Interactive Website is a website that is currently popular. This website users can interact with and also you meet arguments about what they think.

In this study, the website that will be discussed is a more dynamic website. Where The dynamic website will be combined into a data center regarding Gresik History, namely Gresik Historical Medium. The dynamic website was chosen because researchers expect a website that can be accessed not only by website makers but also the local Gresik community, the government, businessmen, and even tourists.

\section{DESIGN THINKING METHOD IN DESIGNING DYNAMIC WEBSITES}

This design uses the Design Thinking method. The purpose of this Design Thinking method is to create a design process that can solve problems accurately. The Design Thinking process goes through several processes to produce effective design products, such as Empathize, Define, Ideate, Prototype, and Test. The process will be repeated until you get the ideal website design results for the target users. The following is a discussion of the dynamic website design process The history of Islam in Gresik which is carried out using the Design Thinking method:

\section{Emphatize}

is observing the behavior of the Gresik community regarding Islamic history. This process is carried out by identifying the factors that influence many people to visit Islamic historical tourism in Gresik. Several methods were carried out, such as observations of the Gresik community and literature studies that supported research on Gresik's Islamic History. Furthermore, interviews with related parties such as Islamic History Experts and the people of Gresik themselves were conducted. The next process is to distribute questionnaires to the public to identify the needs needed to create a dynamic website.

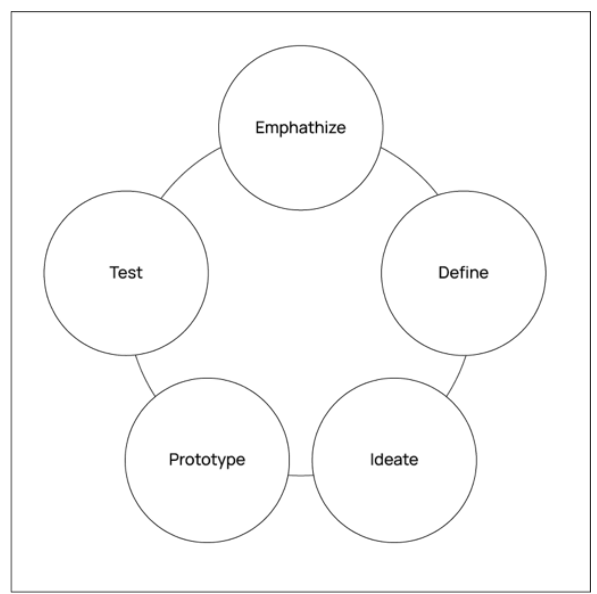

Figure 1. Design Thinking Method

\section{Define}

defines needs that are able to become solutions that can solve problems that occur based on the behavior and habits of the Gresik community. The results of the empathy process obtained several facts that can be processed into a dynamic website design concept. There are several factors that are considered and strengthen the basis of dynamic website design, namely that many people do not know the history of Gresik itself. A lot of information is still messy and not integrated. And the difficulty of finding coherent information or separate data makes people not much aware of the history of Islam in Gresik itself.

\section{Ideate}

is where in this process the aim is to determine the appropriate type of dynamic website based on the define results. The concept applied to this process is 
to map several parts of the classification of needs to find data based on groupings ranging from Books, Articles, Historical Relics, Graves, and Videos.

The main design concept on the landing page of the website is a map of Gresik and has some information and also provided several icon buttons where users can choose and sort out which information they need to open the website. The data will be updated by the central government who is the admin who will be able to provide the latest information so that this website can become an information center for Islamic history in Gresik in the future.

Figure 2 is the flow on the user page where the user is required to $\log$ in to do the tracing needs of anyone who accesses this page which can later become data for the admin. After that the user will be presented with several features including there will be a visual map and display some information that can be filtered based on the user who wants to display which data they want to know starting from data related to books, articles, historical relics, tombs, and videos.

While figure 3 is the flow of the admin page where the admins themselves can be accessed by the government and they are tasked with adding the latest information and data which can later be accessed by the user.

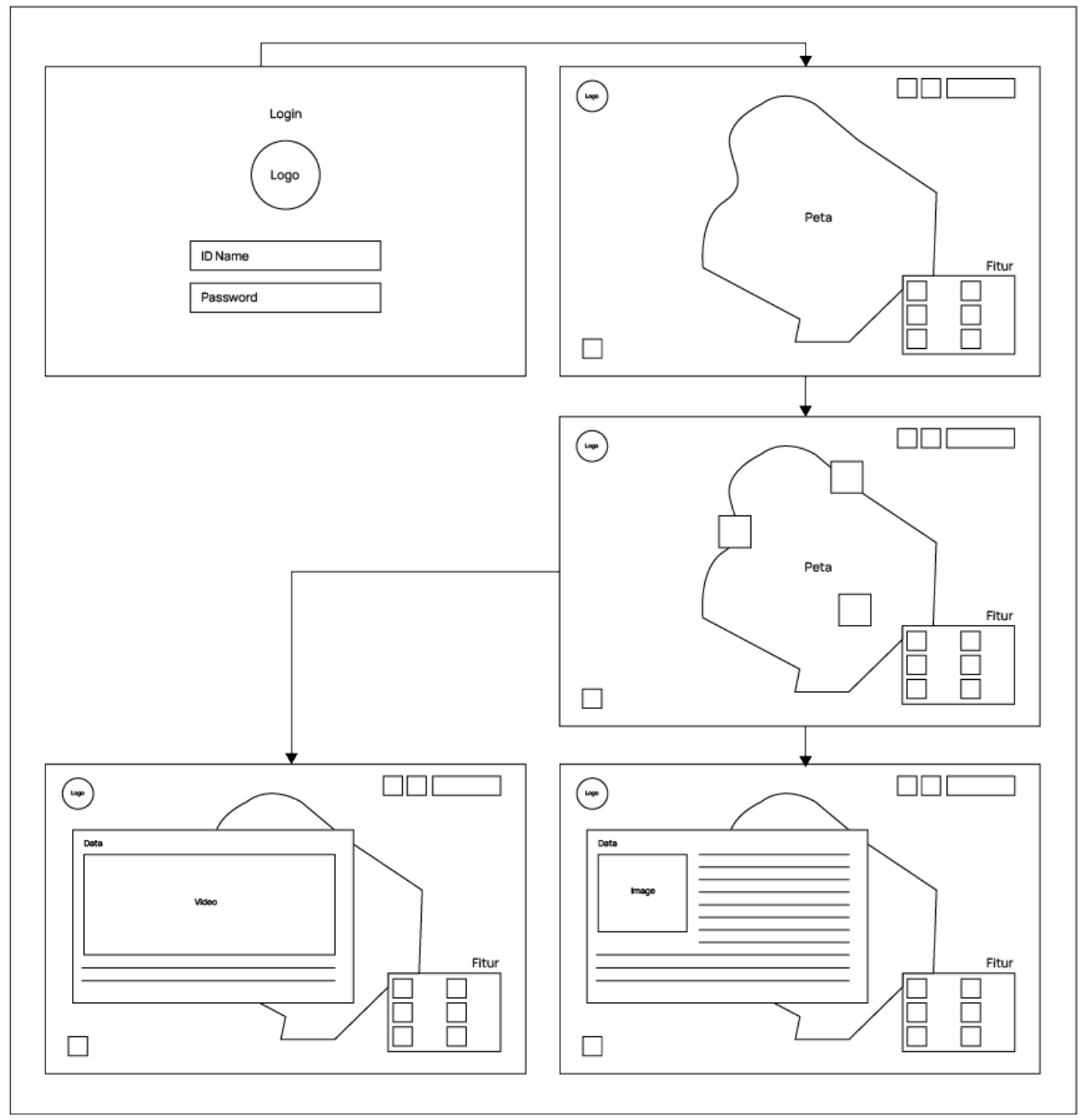

Figure 2. Wireframe Page User 


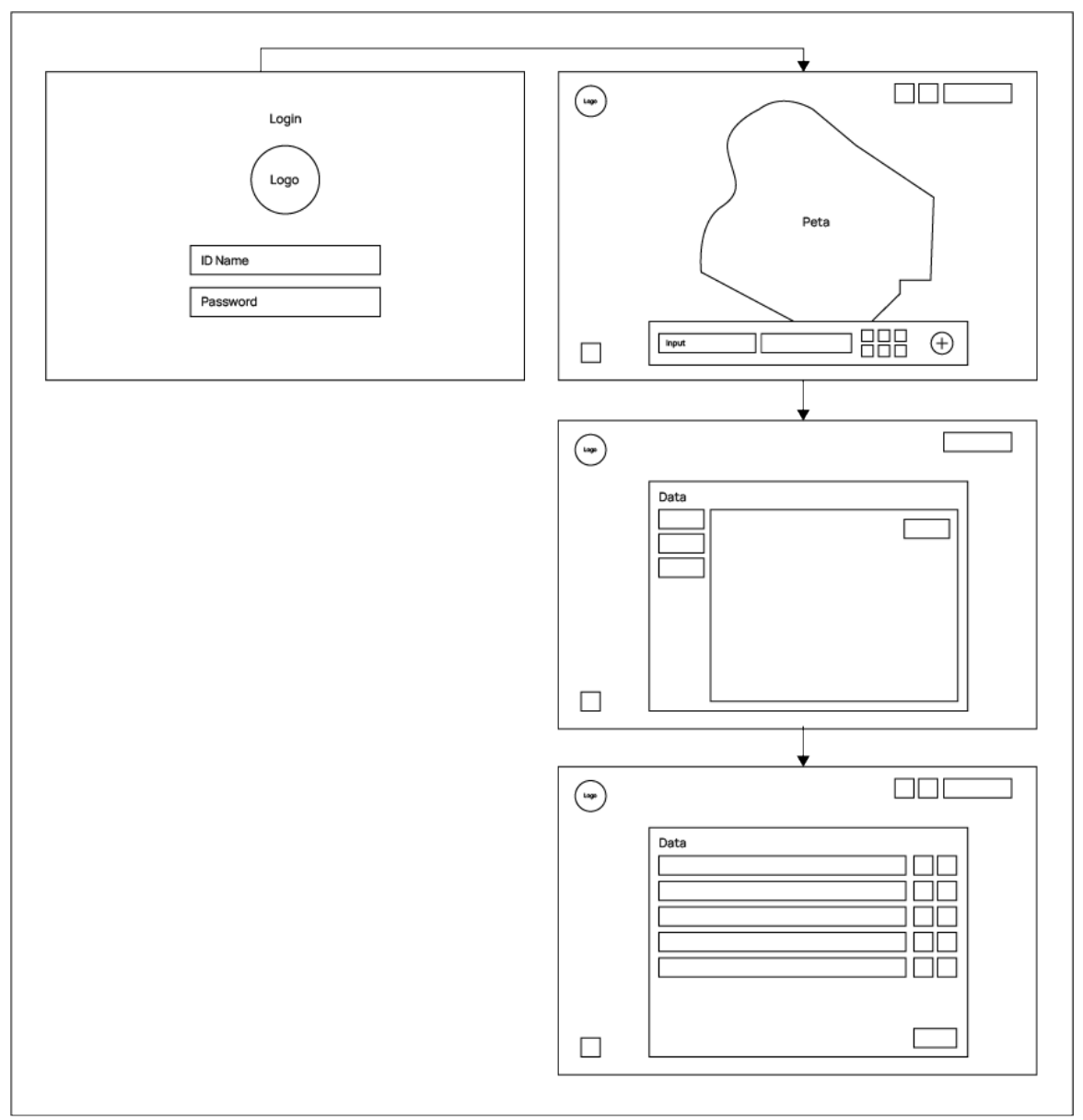

Figure 3. Wireframe Page Admin

\section{Prototype}

In this dynamic website, it is divided into 2 user corners where there is an admin page and a user page. On the first page the user is asked to register using a basic data after that the user will have an account which in the future can be accessed in the future. In a dynamic website, the website has several features that cannot be changed by the user and can be changed by the user. The condition of dynamic websites according to Altstiel \& Grow [6] is a website that has flexibility in changing and adding data but still based on the approval of the website maker. In this case, the website will facilitate users to register/register and contribute to provide data/opinions/testimony that can be uploaded in a special form. This form will be curated by the website admin sequentially to be passed as published data.

Publish the dynamic website of Gresik Islamic History in the form of a map containing several icons consisting of inscriptions, books, articles, tombs, religious tours, historical relics, videos and articles. This map provides directions and information about 7 icons related to the history of Islam in Gresik. This is a dynamic website hierarchy that has been formulated.

a. Login Page

The login page is the home page that will be displayed on the dynamic interface of the Islamic History website in Gresik. This page contains a form for users to register or register. Meanwhile, users who can apply are required to have an email or social media.

It is hoped that the admin can verify the user easily. At the initial prototype stage, the login page will go directly to the main page of the website in the form of a map of Islamic History in Gresik with several features of 7 button icons.

However, in the long term, researchers will create dynamic form pages for users to upload data related to Islamic history in Gresik, such as: new tourist locations, places that have not been explored on the map, or testimonials. 


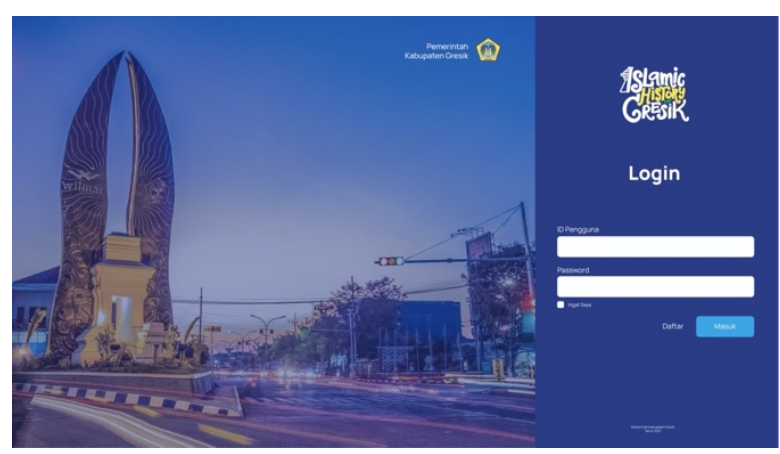

Figure 4. Login Page User

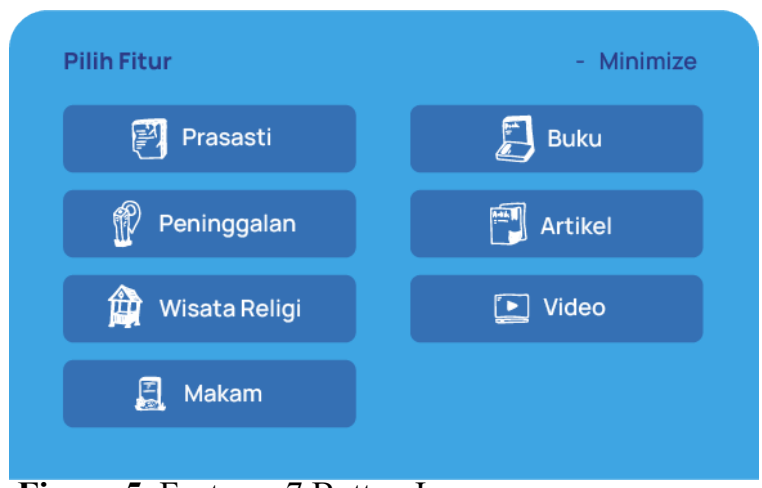

Figure 5. Features 7 Button Icons

\section{b. Main Page}

The main page of the dynamic website contains a digital map in the form of a Gresik map with 7 icons spread. Icons can display further information related to the location or visual experiments that are directly related to Islamic History in Gresik.

c. Information Page

After pressing the desired icon, the user will be directed to a specific link related to the information of each 7 Icons pressed. Each icon contains information, users will find detailed explanations about locations, videos, articles and matters relating to the history of Islam in Gresik.

\section{d. Admin}

The admin is in charge of always updating the latest data that can be shared and managing all types of data that have been summarized and processed for later display to users.

\section{e. Admin Page}

Admins can enter the latest data from Books, Articles, Historical Relics, Graves, and Videos data. Which will be seen by the user after the admin publishes the data.

\section{Test}

Conduct trials on designs and systems that have been made in order to get feedback (criticism and suggestions) from potential users. The feedback obtained will later become a benchmark in improving the design made. This test stage was carried out on 10 Gresik people aged 25-40 years. The tool used is a laptop. After testing this dynamic website, users are given a questionnaire that must be answered based on their experience with the application they have recently used. The results of the data from the trials carried out will later be reprocessed through the empathize stage to find the potential that can be applied to this dynamic website of Islamic history in Gresik.

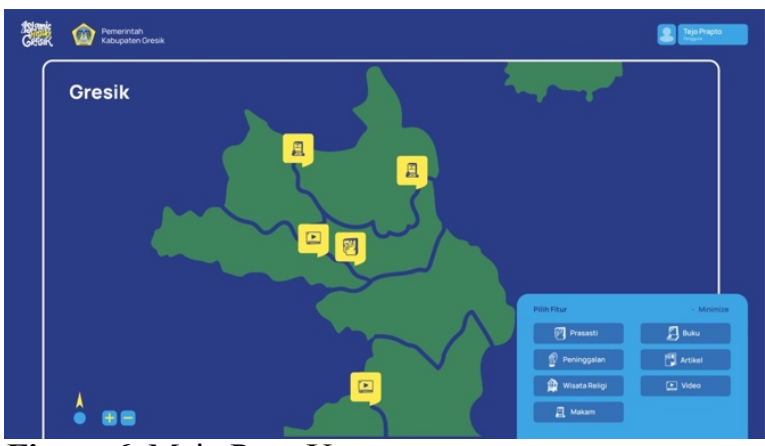

Figure 6. Main Page User

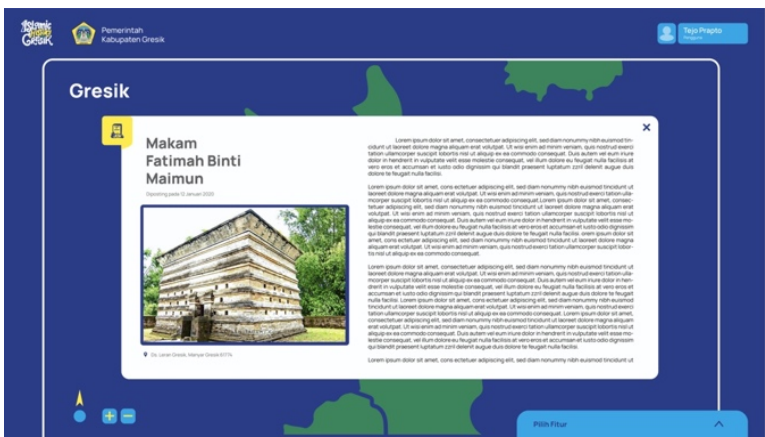

Figure 7. Information Page User

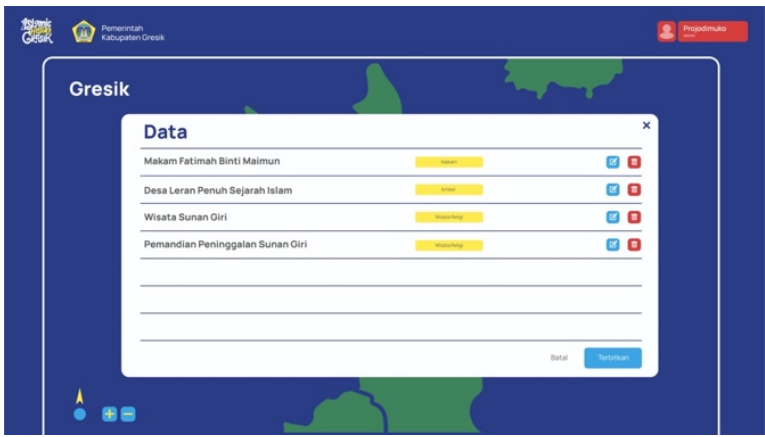

Figure 8. Main Page Admin 


\section{IMPLEMENTATION AND RECOMMENDATION}

The thinking design method requires a fairly long design process with repeated cycles to get the appropriate application design. This dynamic website has the potential to continue to be developed. The involvement of users to provide criticism and suggestions based on the experience of using the website, it is possible that the deficiencies contained in the website can be improved and improved. User participation in preserving history on this website is a potential that can be added to increase the interest of the people of Gresik and Outside Gresik towards Islamic History tourism.

As for the implementation of the dynamic website of the Gresik Islamic History, it is necessary to think about planning for implementation, both short term and long term. This requires active cooperation from various parties, such as: Government, community, historical actors, teachers and community leaders to be able to disseminate information related to the existence of the dynamic website of Gresik Islam History. Researchers recommend to the Government to integrate dynamic websites with existing websites that appear to provide information to potential tourists or Gresik and Outside Gresik residents who want to come or find out about Gresik city. Moreover, in the medium term, several related parties certainly need to create an Integrated Marketing Communication that can promote exclusively about Religious Tourism which is the center of tourists who want to visit Gresik. This recommendation can be used as a reference for further research.

\section{ACKNOWLEDGEMENTS}

This research is supported by the Ministry of Education and Culture Excellence Scholarship which has provided full support for tuition fees. So that this research can be carried out and developed properly.

The researcher also expresses gratitude to the Bandung Institute of Technology family, especially to the 2020 Superior Scholarship friends, for their help and delivery of enthusiasm, as well as to all BU ITB colleagues and families who have provided a lot of physical support.

Researchers should express appreciation to all the people and government of Gresik who joined this research as a case study, for sharing their pearls of wisdom with us during the course of this research. This research is dedicated to the development of Gresik for Indonesia.

\section{REFERENCES}

[1] News Article Liputan 6. Accessed in www.surabaya.liputan6.com; 2021

[2] Mustakim, SS. Gresik Sejarah Bandar Dagang \& Jejak Awal Islam Tinjauan Historis Abad XIII XVII. Jakarta: Citraunggul Laksana; 2005.

[3] Travel Kompas. Accessed in www.travel.kompas.com; 2021

[4] Dinas Kabupaten Gresik. Accessed in www.gresikkab.go.id; 2021

[5] Central Statistic Agency. Accessed in www.bps.go.id; 2021

[6] Altstiel \& Grown. Advertising Strategy Creative Tactics From the Outside/In; 2007 